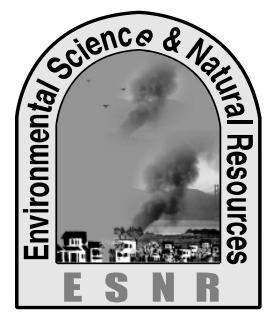

\title{
Spatial Variation of Soil Chemical Properties in Industrial Wastewater Contaminated Paddy Soil
}

\author{
M. S. Hossain ${ }^{1}$, M. H. Kabir², M. M. Rahman', M. S. Alam² and G. K. M. M. Rahman ${ }^{2 *}$ \\ ${ }^{1}$ Department of Soil Science, Sylhet Agricultural University, Sylhet \\ ${ }^{2}$ Department of Soil Science, Bangabandhu Sheikh Mujibur Rahman Agricultural University, \\ Gazipur \\ *Corresponding author: mustafiz@bsmrau.edu.bd
}

\begin{abstract}
Soil quality is essential for sustainable crop production. Excessive or deficient in necessary chemical elements in soil is a concern for soil quality. The study was undertaken to evaluate the impact of chemical industrial wastewater on chemical properties of soil and observe spatial distribution of nutrients in paddy soil adjacent to a chemical industry. A command area comprising a paddy field exposed to a chemical industrial wastewater was selected to study and 10 composite soil samples including a control (not exposed to wastewater) was collected and analyzed. Compared to background values soil $\mathrm{pH}, \mathrm{OC}, \mathrm{N}, \mathrm{P}, \mathrm{Ca}$, and $\mathrm{S}$ were found higher in contaminated soils through the industrial wastewater. The order of the increment of the nutrients in the contaminated soil was as $\mathrm{N}>\mathrm{P}>\mathrm{S}>\mathrm{OC}>\mathrm{Ca}>\mathrm{Na}$. Sulphur and Nitrogen pose as potent elements for toxicity or pollution of the soil exposed to untreated wastewater. Differential spatial variations were observed for various nutrients in the area. Highest spatial variation was observed for $\mathrm{S}$, $\mathrm{N}$ and $\mathrm{B}$ followed by $\mathrm{P}, \mathrm{K}, \mathrm{Ca}, \mathrm{Mg}$ and $\mathrm{Na}$ might be due to anthropogenic activities through industrial untreated wastewater. These issues need to be taken into consideration while recommending fertilizers for crops grown in this type of command area.
\end{abstract}

Key words: Accumulation, Index, Map, Nutrient and Soil quality

\section{Introduction}

Soil quality or soil health is essential for sustainable agriculture which is currently a burning issue for feeding quality food to increasing global population utilizing limited land resources. Soil quality is being degraded due to many anthropogenic activities including disposal of untreated industrial effluents and wastewater into land. The quality of soil is generally assessed based on only chemical indices. The application of industrial waste can either stimulate soil microbial activity, due to an increase in available carbon and nutrients, or inhibit activity due to the presence of heavy metals and other pollutants. Different studies reported industrial effluent contamination or wastewater irrigation can alter soil properties including soil infiltration rate, hydraulic conductivity, bulk density, porosity, $\mathrm{pH}$, organic carbon and nutrient contents (Valdes et al., 1996; Seneviratne, 1997; Kaur and Sharma, 2013). Effluents may vary in composition and quality depending on the types of industry from which they have been originated. Wastewater contains considerable amounts of nutrients such as N, P, K, Ca and S (Chhonkar et al., 2000). The available macronutrients and micronutrients of effluents can increase soil fertility. The use of wastewater for irrigation is increasingly being considered as a technical solution to minimize soil degradation and to restore nutrient content of soils. Conversely, the waste material discharges from industrial activities cause adverse effects on soil and soil organic matter and untreated effluents can be a major source of soil pollution (WHO, 1977). Industrial effluent causes serious heavy metal pollution and poses ecological risk (Ogunkunle and Fatoba, 2012). The industrial effluents and water drainage from spoil and rubbish heaps either wash directly to nearby lands or to water bodies.

Rapid and unplanned urbanization and industrialization triggers much production of such chemicals and wastewater that affect soil health. Even industrial zone has been expanded to the rural areas ignoring industrialization rules and regulation that increased the tendency for using wastewater for irrigation in the crop field. Most of the industries in Bangladesh seldom treat discharged wastewater using treatment plant that result in the flooding nearby land, mostly paddy fields with the untreated wastewater. Application of untreated wastewater to irrigated rice fields is a concern for probable health risks associated with the consumption of contaminated crop or rice grain.

The use of wastewaters for agriculture is marred due to various problems like soil salinity, interaction of chemical constituents of the wastes with the uptake of nutrients and changes in soil property and micro flora. Industrial and domestic effluents are either used or disposed off on land for irrigation purposes that create both opportunities and problems. But very limited and scattered researches have been done in Bangladesh focusing in these issues. Therefore, it is urgently needed to do systematic research in Bangladesh to quantify chemicals in contaminated soil and their impact on soil health and crop production. Considering the above points, the investigation was undertaken to evaluate the impact of industrial wastewater on chemical properties of soil and observe spatial variations of nutrients in paddy soil adjacent to a chemical industry.

\section{Materials and Methods}

\section{Study area}

A highly contaminated paddy field command area adjacent to the discharge point of a chemical industry was selected for the present study. It is located at South Donua, Sreepur of Gazipur district of Bangladesh lies between $90.388^{\circ}$ North latitude and $24.253^{\circ}$ East longitude (Fig. 1). This Chemical Industry Limited manufactures and sells chemicals in Bangladesh. The main products of this industry are dye, sulphuric acid, 
bleaching, explosives, storage battery, rayon, water purification, heavy chemical etc.

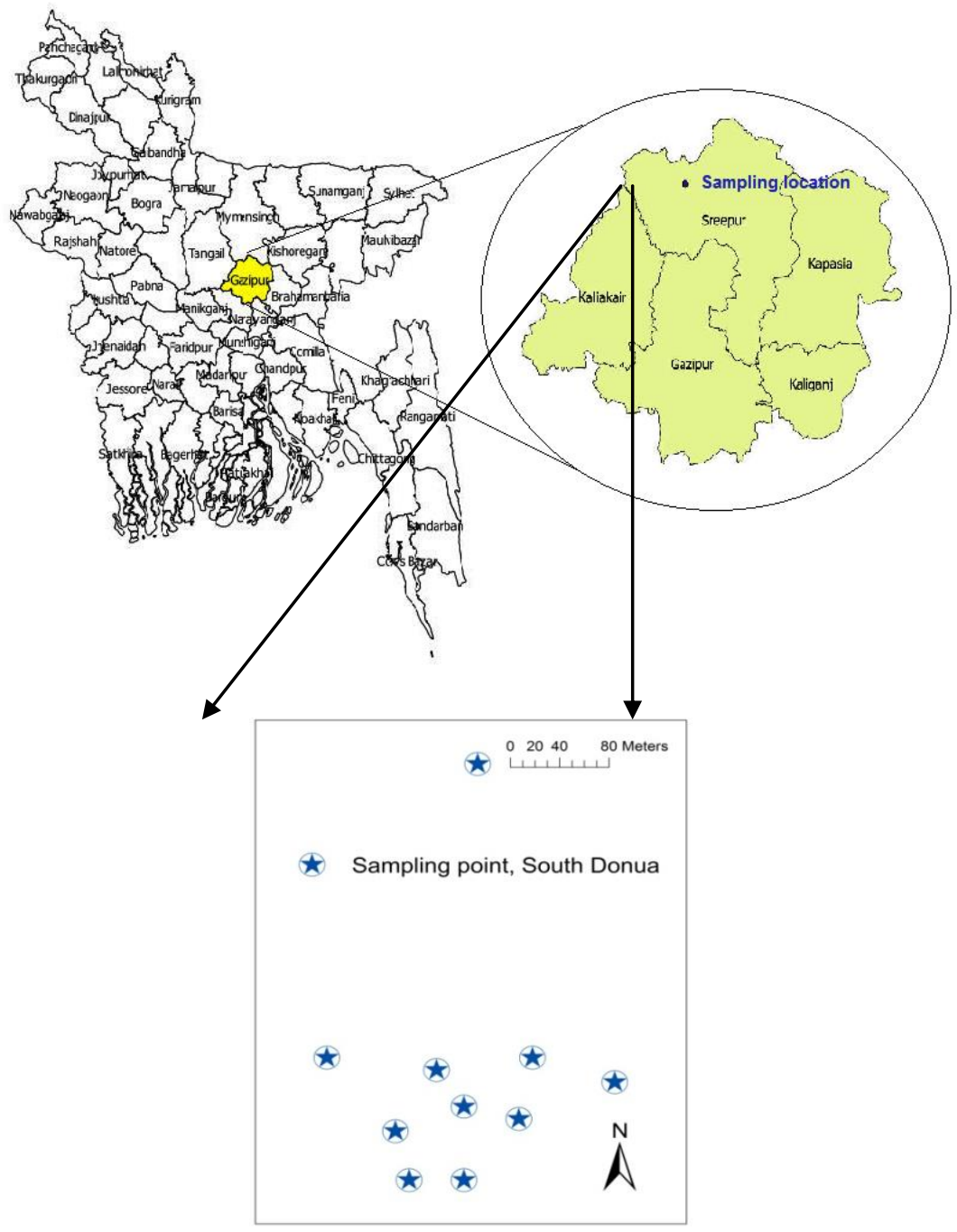

Fig. 1. Map showing sampling site of the study area

\section{Soil sample collection}

A total of 10 soil samples including one control (where effluent does not reach absolutely) were collected from the command area of the chemical industry under study. An equal $15 \mathrm{~m}$ distance from one sampling point to another sampling point was possibly maintained in the whole command area. Each sample was the composite of at least 5 sub-samples within a distance of $2 \mathrm{~m}$ surrounding a specific sampling location. At least $2.5 \mathrm{~kg}$ georeferenced (with longitude and latitude) soil sample was collected using a portable global position system (GPS, Garmin 60CSx).

\section{Soil Sample processing and chemical analyses}

Soil samples were air dried, cleaned and homogenized with Vibrating Sample Mill, HEIKO-TI-200 and sieved using $2 \mathrm{~mm}$ sieve. Soil $\mathrm{pH}$ was determined at the soil and water ratio of 1:2.5 as outlined by Jackson (1973). The total organic carbon in soil was estimated by wet oxidation method devised by Walkey and Black (1935).
Total nitrogen was determined by Kjeldahl Method following concentrated sulphuric acid digestion and steam distillation with $40 \% \mathrm{NaOH}$. Available phosphorus in soil samples was determined following the method described by Olsen et al., (1954). Exchangeable $\mathrm{K}, \mathrm{Ca}, \mathrm{Mg}$ and $\mathrm{Na}$ were determined by $\mathrm{N}$ $\mathrm{NH}_{4} \mathrm{OAc}$ extraction method as described by Jackson (1973). Available sulfur was determined turbidimetrically using barium sulfate and reading was taken by Double Beam Spectrophotometer (Chesnin and Yien, 1951). Boron content was determined by DTPA extraction method.

\section{Defining nutrient accumulation and nutrient toxicity indices}

We defined the following indices.

Chemical accumulation index $(\mathrm{CAI})=\mathrm{C}_{\text {cont }} / \mathrm{C}_{\text {background }}$

Nutrient toxicity index $(\mathrm{NTI})=\frac{\mathrm{Ncont}-\mathrm{Ncl} * 4.0}{\mathrm{Ncl}}$ 
Where $\mathrm{C}_{\text {cont }}$ is the chemical/nutrient concentration in contaminated soil (soil exposed to effluents/wastewater), $\mathrm{C}_{\text {background }}$ is the concentration of chemical/nutrients in soil not exposed to effluents/wastewater, $\mathrm{N}_{\mathrm{cl}}$ is the critical nutrient concentration, $\mathrm{Ncl}^{*} 4.0$ is considered as very high level of nutrient concentration when plant response to added nutrient is very unlikely (FRG, 2012). CAI is comparable to the single factor pollution index as described by CGFDC (1994). Based on the indices formulae, indices values were computed for the nutrient elements under study. Critical nutrient concentration was for wetland rice crops grown loamy clayey soils (FRG, 2012).

\section{Statistical and geo-statistical analyses}

Statistical analysis was performed using $\mathrm{R}$ and spreadsheet software packages. Geo-statistical analyses were performed for visualization outputs maps. Inverse Distance Weighting (IDW) method was employed to produce spatial patterns of $\mathrm{N}, \mathrm{P}, \mathrm{K}, \mathrm{Ca}, \mathrm{Mg}, \mathrm{Na}, \mathrm{S}$ and $\mathrm{B}$ in the command area.

\section{Results and Discussion}

\section{Nutrients accumulation in the study area soil through contaminated industrial wastewater}

The concentrations of nutrients along with control sample under the chemical industry are summarized in Table 1. Mean values of $\mathrm{pH}, \mathrm{OC}, \mathrm{N}, \mathrm{P}, \mathrm{K}, \mathrm{Ca}, \mathrm{Mg}, \mathrm{Na}$, $\mathrm{S}$ and $\mathrm{B}$ were $5.31,0.76 \%, 0.53 \%, 10.16 \mathrm{mg} \mathrm{kg}^{-1}$, $0.21 \mathrm{meq} 100 \mathrm{gm}^{-1}, 5.39 \mathrm{meq} 100 \mathrm{gm}^{-1}, 0.91 \mathrm{meq} 100 \mathrm{gm}^{-1}$, $0.56 \mathrm{meq} 100 \mathrm{~g}^{-1}, 162.08 \mathrm{mgkg}^{-1}$ and $0.50 \mathrm{mgkg}^{-1}$, respectively. The Chemical accumulation index (CAI) values greater than the unity were observed for $\mathrm{pH}, \mathrm{OC}$, $\mathrm{N}, \mathrm{P}, \mathrm{Ca}, \mathrm{Na}$ and $\mathrm{S}$, thereby enriching the chemical properties in soil through effluent wastewater. The highest concentration of $S$ was observed in both contaminated and uncontaminated soils under this command area. The value of CAI for $\mathrm{S}$ is 2.70 indicating that contaminated soil contains more than two times of $\mathrm{S}$ than uncontaminated soil. The very high value of nutrient toxicity index (NTI) for S (12.21) signifies the potential toxicity of soil by S. Nitrogen got a highest CAI value which was around 19 indicating most accumulation of $\mathrm{N}$ than other elements from waste water. Next to $\mathrm{S}, \mathrm{N}$ may be a potential pollutant as indicated by NTI value which is 0.46. Nitrogen pollution may lead to eutrophication and enhanced emission of greenhouse gases (NOx) in the wetland paddy field. The buildup of organic carbon $(\mathrm{CAI}=1.44)$ is one of the reasons of nitrogen deposition in the contaminated soil. Phosphorus concentration in contaminated soil was around 5 times higher than uncontaminated soil as denoted by CAI value for phosphorus, although this amount of $\mathrm{P}(\mathrm{NTI}=-2.73)$ is not too high to pollute a paddy soil. The increase of $\mathrm{pH}$ value $(\mathrm{CAI}=1.06)$ in contaminated soil is due to increase the concentration of some exchangeable bases like $\mathrm{Na}$ and $\mathrm{Ca}$. The higher $\mathrm{CV}$ values were observed for $\mathrm{S}, \mathrm{N}, \mathrm{P}$ and $\mathrm{B}$ than the other nutrients representing the greatest spatial variation in contaminated soil (Table 1). This indicated that the highest influence of industrial effluent on S, N, P and B for the chemical industrial area soil. Liu et al. (2003) also mentioned that anthropogenic sources of chemicals gradually build up in soil. The lower $\mathrm{CV}$ for $\mathrm{pH}, \mathrm{Ca}, \mathrm{Mg}$ and $\mathrm{K}$ were 3.95, $22.74,27.64$ and $34.17 \%$, respectively indicating a low spatial variation. Table 1 shows the uniform distribution of chemical properties in the command area was as proved by the value of Kurtosis $(<3)$. The contamination potential of individual chemical element followed the order of $\mathrm{N}>\mathrm{P}>\mathrm{S}>\mathrm{OC}>\mathrm{Ca}>\mathrm{Na}$.

Table 1. Descriptive statistics of the chemical parameters of soils with accumulation/toxicity indices values

\begin{tabular}{|c|l|l|l|l|l|l|l|l|l|l|}
\hline Parameters & $\mathrm{C}_{\text {backg }}$ & Mean & CAI & NTI & SD & Kurt & Skew & Min & Max & $\begin{array}{l}\text { CV } \\
(\%)\end{array}$ \\
\hline $\mathrm{pH}$ & 5.01 & 5.31 & 1.06 & ----- & 0.21 & -1.74 & 0.09 & 5.01 & 5.59 & 3.95 \\
\hline $\mathrm{OC}(\%)$ & 0.53 & 0.76 & 1.44 & ----- & 0.29 & 0.08 & 0.46 & 0.33 & 1.31 & 37.62 \\
\hline $\mathrm{N}(\%)$ & 0.03 & 0.53 & 19.10 & 0.46 & 0.51 & -1.27 & 0.71 & 0.03 & 1.37 & 95.14 \\
\hline $\mathrm{P}(\mathrm{mg} / \mathrm{kg})$ & 1.80 & 10.16 & 5.65 & -2.73 & 3.94 & 1.33 & -0.91 & 1.80 & 15.89 & 38.78 \\
\hline $\mathrm{K}(\mathrm{meq} / 100 \mathrm{~g})$ & 0.39 & 0.21 & 0.53 & -2.28 & 0.07 & 5.54 & 1.97 & 0.12 & 0.39 & 34.17 \\
\hline $\begin{array}{c}\mathrm{Ca} \\
(\mathrm{meq} / 100 \mathrm{~g})\end{array}$ & 3.80 & 5.39 & 1.42 & -1.30 & 1.23 & 0.22 & 0.75 & 3.80 & 7.80 & 22.74 \\
\hline $\begin{array}{c}\mathrm{Mg} \\
(\mathrm{meq} / 100 \mathrm{~g})\end{array}$ & 1.21 & 0.91 & 0.75 & -2.18 & 0.25 & -1.42 & -0.34 & 0.51 & 1.21 & 27.64 \\
\hline $\begin{array}{c}\mathrm{Na} \\
(\mathrm{meq} / 100 \mathrm{~g})\end{array}$ & 0.46 & 0.56 & 1.24 & ----- & 0.19 & 5.48 & 2.14 & 0.39 & 1.05 & 33.55 \\
\hline $\mathrm{S}(\mathrm{mg} / \mathrm{kg})$ & 59.96 & 162.8 & 2.70 & 12.21 & 225.8 & 2.64 & 1.93 & 17.0 & 680.2 & 139.35 \\
\hline $\mathrm{B}(\mathrm{mg} / \mathrm{kg})$ & 0.66 & 0.50 & 0.75 & -1.52 & 0.22 & -0.52 & -0.27 & 0.10 & 0.82 & 44.87 \\
\hline
\end{tabular}

$\mathrm{C}_{\text {backg }}$ : Background value of nutrient/chemical; CAI: Nutrient/chemical accumulation index; NTI: Nutrient toxicity index; SD: standard deviation; CV: coefficient of variation; Kurt: Kurtosis; Skew: Skewness; Min: Minimum; Max: Maximum 
Spatial variation of the nutrient elements of the wastewater contaminated soils

The inverse distance weighting (IDW) interpolation was used to obtain filled contour maps for spatial
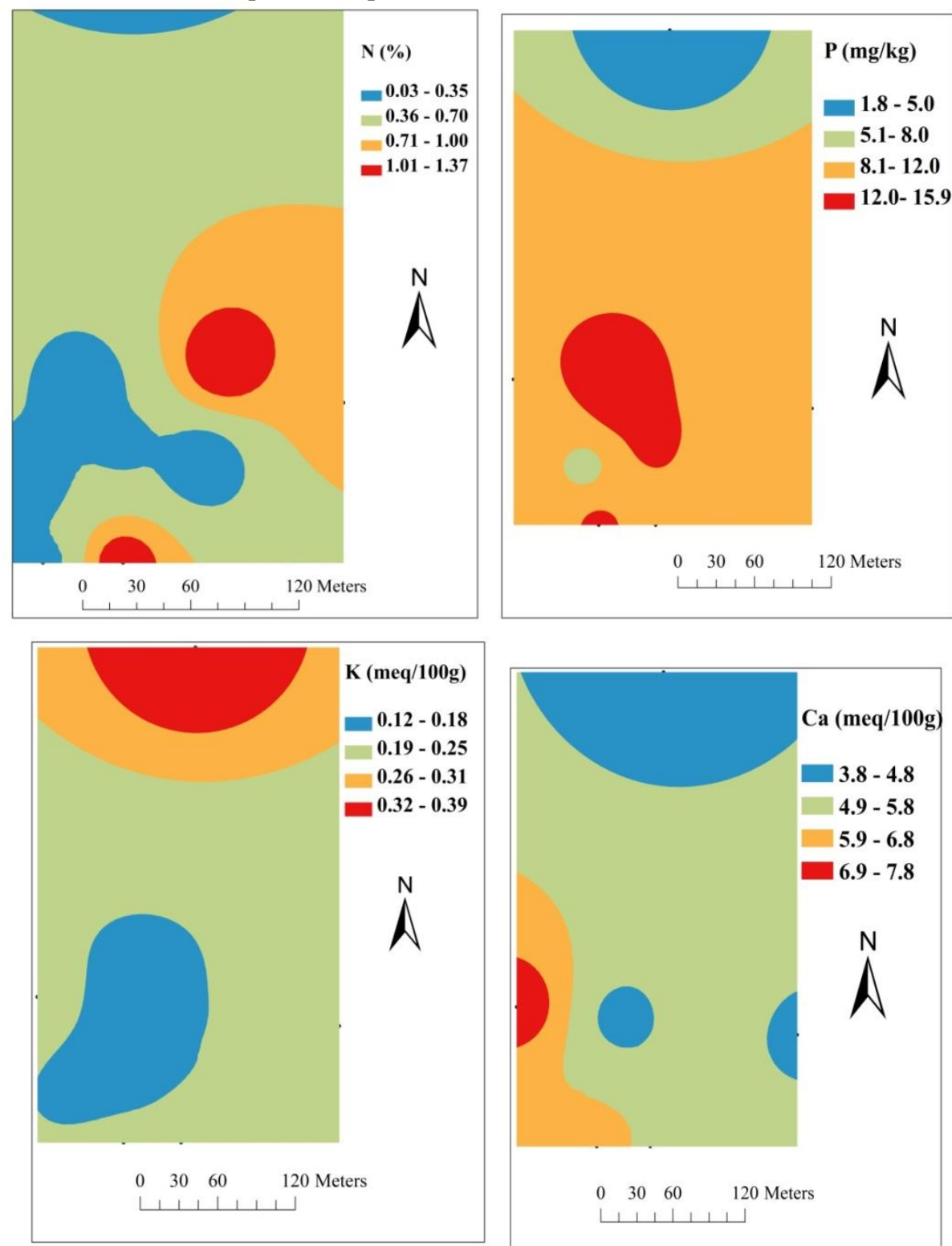

Fig. 2(a). Spatial variation of N, P, K and Ca in the paddy field soil in the command area under chemical industry 

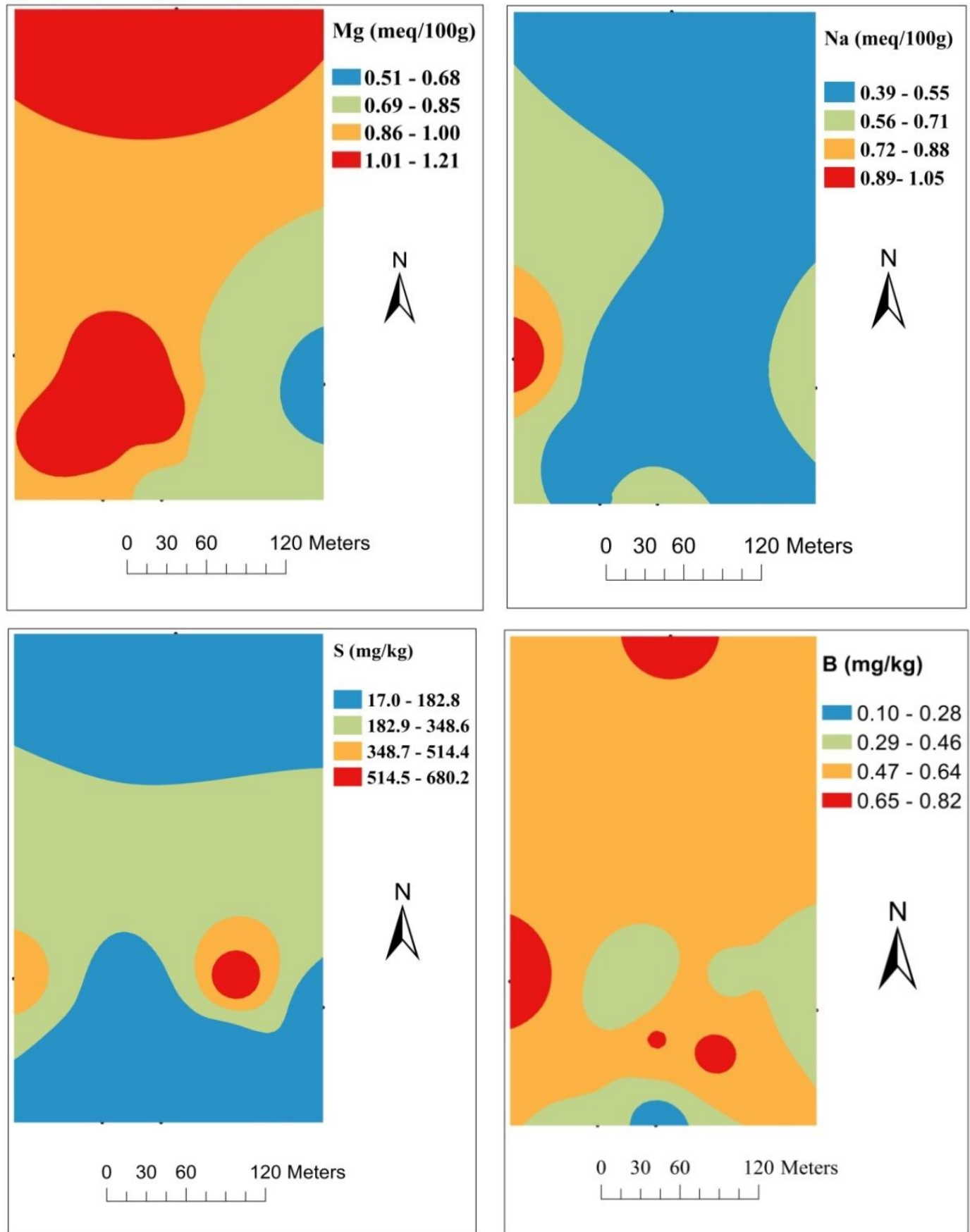

Fig. 2 (b). Spatial variation of $\mathrm{Mg}, \mathrm{Na}, \mathrm{S}$ and $\mathrm{B}$ in the paddy field soil in the command area under chemical industry

Their spatial distribution maps provide the visual display of nutrient elements distribution variation in the command area. As shown in Fig. 2 that the highest variation was observed for $\mathrm{S}, \mathrm{N}$ and $\mathrm{B}$ followed by $\mathrm{P}$, $\mathrm{K}, \mathrm{Ca}, \mathrm{Mg}$ and $\mathrm{Na}$ might be due to anthropogenic activities through untreated waste water from the chemical industries. The results of the many studies (Facchinelli et al., 2001 and Martín et al., 2006) in different industrial contaminated sites in other countries also revealed the spatial structures of chemical elements in paddy field soils.

\section{Conclusions}

Elevated concentrations of nutrients accumulation were detected in the chemical industrial command areas as compared to background values of control soil. Soil $\mathrm{pH}$, $\mathrm{OC}, \mathrm{N}, \mathrm{P}, \mathrm{Ca}$, and $\mathrm{S}$ were found higher in contaminated soils compared to background value and indicated the increasing trend in accumulation of these nutrients from waste water. Sulphur and Nitrogen pose as potential elements for pollution of soil exposed to chemical industrial wastewater. Difference in spatial variation of nutrients in the study area is attributed by the differently contamination pattern of the nutrient elements 
concerned. These issues need to be taken into consideration while recommending fertilizers for crops

\section{References}

CGFDC (China Green Food Development Center). 1994. Environmental Quality Assessment for Green Food Production Program. Science Press, Beijing. (In Chinese)

Chesnin, L. Y. and Yien, C. H. 1951. Turbidimetric determination of available sulphate. Proceedings of Soil Science Society of America, 15: 149-1.

Chhonkar, P. K.; Datta, S. P.; Joshi, H. C. and Pathak, H. 2000. Impact of industrial effluents on soil health and agriculture-Indian experience: Part-I, distillery and paper mill effluents. Journal Scientific and Industrial Research, 59: 350-361.

Facchinelli, A.; Sacchi, E. and Mallen, L. 2001. Multivariate statistical and GIS-based approach to identify heavy metal sources in soil. Environmental Pollution, 114: 313-324.

FRG (Fertilizer Recommendation Guide). 2012. Bangladesh Agricultural Research Council (BARC), Farmgate, Dhaka, 274p.

Jackson, M. L. 1973. Soil Chemical Analysis, Prentice Hall of India Pvt. Ltd., New Delhi, 38-56.

Kaur, V. and Sharma, G. 2013. Effect of industrial effluents on soil characteristics-A review. International Journal in Advances in Engineering Science and Technology, 3(3): 201-207

Liu, X.; Wu, J. and Xu, J. 2006. Characterizing the risk assessment of heavy metals and sampling uncertainty analysis in paddy field by geostatistics and GIS. Environmental Pollution, 141: 257-64. grown in this command area.

Martín, J. A. R.; Arias, M. L. and GrauCorbí, J. M. 2006. Heavy metals contents in agricultural topsoils in the Ebro basin (Spain): Application of the multivariate geostatistical methods to study spatial variations. Environmental Pollution, 144: 10011012.

Ogunkunle, C. O. and Fatoba, P. O. 2013. Pollution loads and the ecological risk assessment of soil heavy metals around mega cement factory in southwest Nigeria. Polish Journal of Environmental Studies, 22(2): 487-493.

Olsen, R.; Cole, C. V.; Watanabe, F. S. and Dean, L. A. 1954. Estimation of available phosphorus in soils by extraction with sodium bicarbonate. USDA Circular No. 939 USDQ, 1-19.

Seneviratne, N. M. G. 1997. Waste water from raw rubber processing industry in Srilanka and related environmental aspects. Bulletin of the Rubber Research Institute of Sri Lanka, 35: 42-48.

Valdes, E.; Obaya, M. C. and Ramos, J. 1996. Ecology and the sugar industry Revista, 30: 214-229.

Walkley, A. and Black, C. A. 1935. An examination of the method for determining soil organic matter and proposed modification of the chromic acid titration method. Soil Science, 37: 29-39.

WHO (World Health Organization). 1997. International Stands for Drinking Water. Cited from Ground Water Assessment Development and Management, 248-249 